\section{УДК: 351.814.1-005.52:005334}

Непомнящий Олександр Михайлович, доктор наук з державного управління, академік Академії будівництва України, професор кафедри публічного адміністрування, Міжрегіональна Академія управління персоналом, 03039, м. Киів, вул. Фрометівська, 2, тел.: (044) 49095 00, е-таil: n_a_m@ukr.net

ORCID: 0000-0002-5766-3150

Непомнящий Александр Михайлович, доктор наук по государственному управлению, академик Академии строительства Украины, профессор кафедры публично$2 о$ администрирования, Межрегиональная Академия управления персоналом, 03039, 2. Киев, ул. Фрометовская, 2, тел.: (044) 49095 00,e-mail:n_a_m@ukr.net

ORCID: 0000-0002-5766-3150

\section{Nepomnyashchyi Oleksandr}

\section{Mykhailovych,}

Doctor of science in Public Administration, Academician of Academy of building of Ukraine, Professor of the Department of Public Administration, Interregional Academy of Personnel Management, 03039, Kyiv, Str. Frometivska, 2, (044) 49095 00, e-mail:n_a_m@ukr.net

ORCID: 0000-0002-5766-3150

Барзилович Дмитро Владиславович, Президент, Всеукраїнська громадська організація "Асоціація експертів будівельної галузі", 02000, м. Киів, проспект Соборності, 15/17, тел.: (097) 25543 54, е-таil: akela16@ukr.net

ORCID: 0000-0002-5766-3150

Барзилович Дмитрий Владиславович, Президент, Всеукраинская общественная организация "Ассоциачия экспертов строительной отрасли”, 02000, г. Киев, проспект Соборности, 15/17, тел.: (097) 255 4354,e-mail:akela16@ukr.net

ORCID: 0000-0002-5766-3150

\section{Barzylovich Dmitry Vladislavovich,}

President, Ukrainian Public Organization "Association of Building Industry Experts", 02000, Kyiv, Prospect Sobornosti, 15/17, tel.: (097) 25543 54, e-mail: akela16@ukr.net

ORCID: 0000-0002-5766-3150
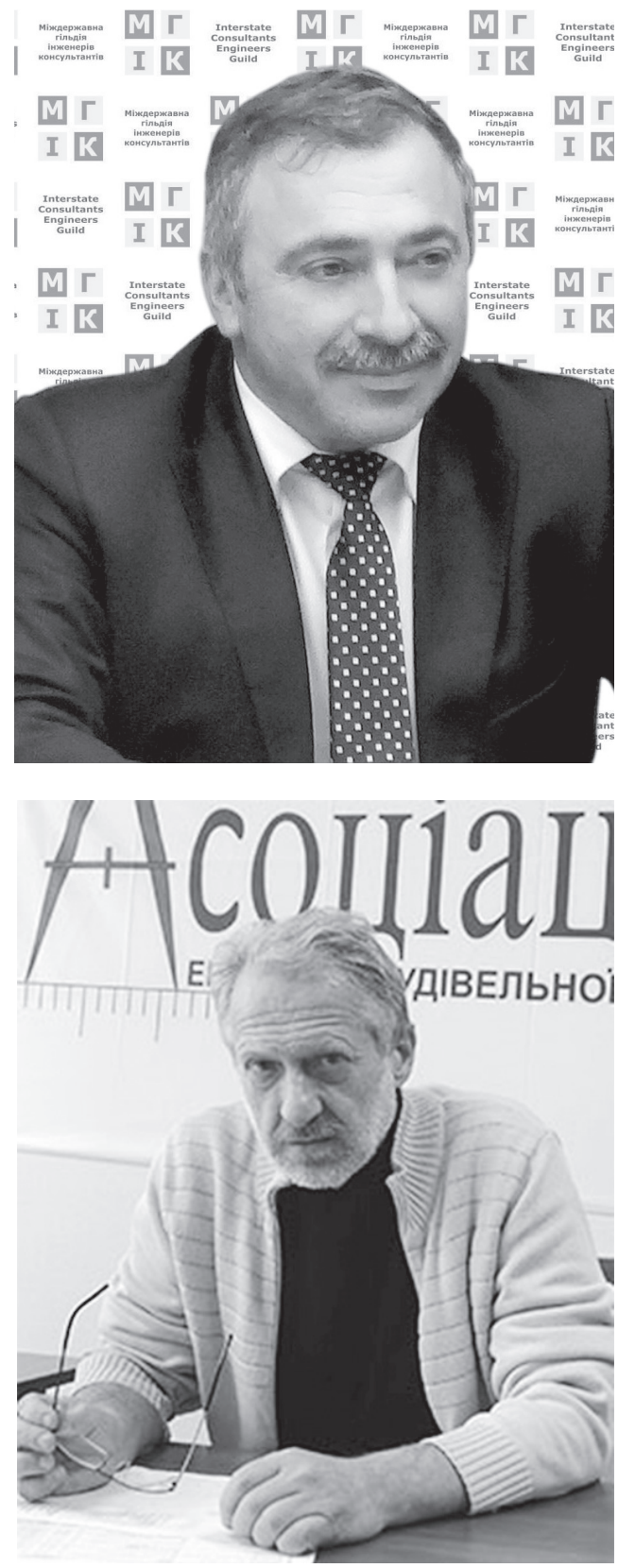


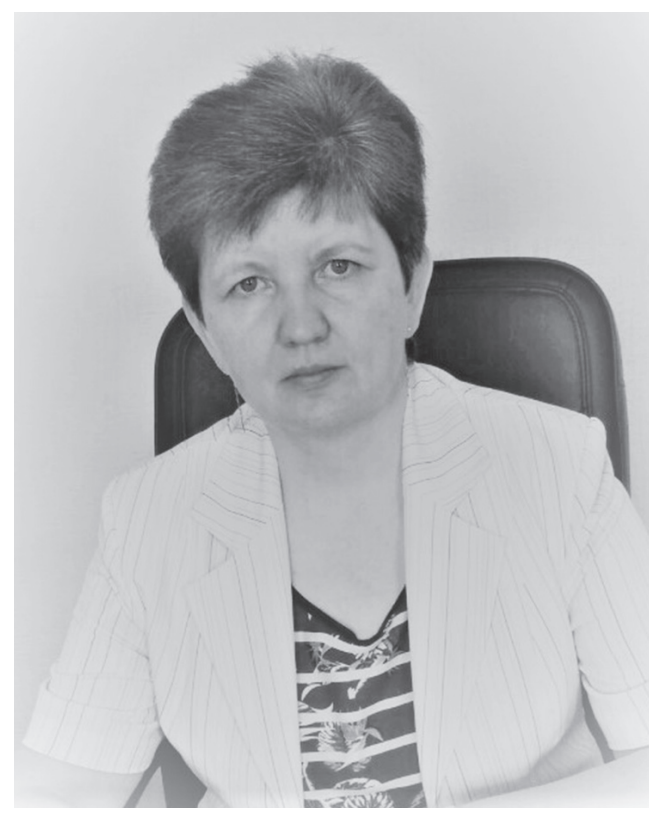

Медведчук Оксана Валерївна, аспірант кафедри публічного адміністрування, Міжрегіональна Академія управління персоналом, 03039, м. Київ, вул. Фрометівська, 2, тел.: (044) 49095 00, е-таil: medvedchuk o@ukr.net ORCID: 0000-0002-2795-8193

\section{Медведчук Оксана Валеръевна,} аспирант кафедры публичного администрирования, Межрегиональная Академия управления персоналом, 03039, г. Киев, ул. Фрометовская, 2, тел.: (044) 4909500 , e-mail:medvedchuk_o@ukr.net

ORCID: 0000-0002-2795-8193

Medvedchuk Oksana Valeriyozna, postgraduate student of the Department of Public Administration, Interregional Academy of Personnel Management, 03039, Kyiv, Str. Frometivska, 2, tel.: (044) 4909500 , e-mail:medvedchuk_o@ukr.net

ORCID: 0000-0002-2795-8193

DOI: 10.32689/2617-2224-2018-15-5-195-209

\section{РИЗИК-МЕНЕДЖМЕНТ ЯК ІНСТРУМЕНТАРІЙ ДЕРЖАВНОГО РЕГУЛЮВАННЯ ОЦІНКИ РИЗИКІВ ПРИ БУДІВНИЦТВІ ТА ЕКСПЛУАТАЦІї СПОРУД}

Анотація. Визначено актуальність і необхідність удосконалення механізмів державного регулювання економічних відносин у країні. На сьогодні існує безліч апробованих світовим досвідом кількісних, описових, імітаційних підходів до управління ризиком інвестиційного проекту в реальному секторі. Їх вибір потребує врахування особливостей державного регулювання будівельної галузі на засадах ризик-менеджменту. Методи оцінювання ризиків розглядаються у працях вітчизняних і зарубіжних вчених, зокрема таких, як С. Болотін [3], Н. Бланас, К. Сіракуліс та Х. Пандемменоу [19], В. Кошелев [8], О. Кружилко [9], Т. Морозова [11], І. Птухіна [12], А. Шниров [13], С. Шульженко [14], С. Хендріксон [16]. Зазначено, що недостатньо опрацьованими залишаються особливості державного регулювання діяльності суб'єктів будівельної галузі та комплексне розуміння усіх переваг і недоліків різних методів оцінювання ризиків у будівництві. Обгрунтовано, що основним завданням аналізу ризику інвестором є побудова коректної моделі (подання) проекту, яка використовується для прийняття рішення про фінан- 
сування спорудження того чи іншого об'єкта. Базові групи методів аналізу ризику фінансування проекту інвестором легко визначити по ключовому предмету розгляду - це може бути або схема фінансових потоків, що виникають при його фінансуванні, або власне проект як соціально-економічний феномен. Зроблено висновок, що використання ризик-менеджменту в управлінні інвестиційно-будівельними проектами виступає сучасним інструментарієм механізму державного регулювання та управління ризиками організацій будівельного комплексу.

Ключові слова: державне регулювання у сфері будівництва, ризик-менеджмент, методи оцінювання ризиків, інвестиційно-будівельні проекти.

\section{РИСК-МЕНЕДЖМЕНТ КАК ИНСТРУМЕНТАРИЙ ГОСУДАРСТВЕННОГО РЕГУЛИРОВАНИЯ ОЦЕНКИ РИСКОВ ПРИ СТРОИТЕЛЬСТВЕ И ЭКСПЛУАТАЦИИ СООРУЖЕНИЙ}

Аннотация. Определена актуальность и необходимость совершенствования механизмов государственного регулирования экономических отношений в стране. На сегодня существует множество апробированных мировым опытом количественных, описательных, имитационных подходов к управлению риском инвестиционного проекта в реальном секторе. Их выбор требует учета особенностей государственного регулирования строительной отрасли на основе риск-менеджмента. Методы оценки рисков рассматриваются в трудах отечественных и зарубежных ученых, в частности таких, как С. Болотин [3], Н. Бланас, К. Сиракулис и Х. Пандемменоу [19], В. Кошелев [8], А. Кружилка [ 9], Т. Морозова [11], И. Птухин [12], А. Шныров [13], С. Шульженко [14], С. Хендриксон [16]. Отмечено, что недостаточно проработанными остаются особенности государственного регулирования деятельности субъектов строительной отрасли и комплексное понимание всех преимуществ и недостатков различных методов оценки рисков в строительстве. Обосновано, что основной задачей анализа риска инвестором является построение корректной модели (представления) проекта, которая используется для принятия решения о финансировании строительства того или иного объекта. Базовые группы методов анализа риска финансирования проекта инвестором легко определить по ключевому предмету рассмотрения - это может быть либо схема финансовых потоков, возникающих при его финансировании, или собственно проект как социальноэкономический феномен. Конкретизировано, что использование рискменеджмента в управлении инвестиционно-строительными проектами выступает современным инструментарием механизма государственного регулирования и управления рисками организаций строительного комплекса.

Ключевые слова: государственное регулирование в сфере строительства, риск-менеджмент, методы оценки рисков, инвестиционно-строительные проекты. 


\section{RISK-MANAGEMENT AS AN INSTRUMENT OF THE PUBLIC REGULATION OF RISK ASSESSMENT IN CONSTRUCTION AND OPERATION OF BUILDINGS}

Abstract. The urgency of the article lies in the need of improving the mechanisms of public regulation of economic relations in the country. To date, there are many internationally recognized quantitative, descriptive, and imitative approaches to the managing the risk of an investment project in the real sector. Their choice requires taking into account the peculiarities of public regulation of the construction industry on the basis of risk management. Methods of risk assessment are considered in the works of domestic and foreign scientists, in particular such as S. Bolotin [3], N. Blanas, C. Syraculis and H. Pandemmenou [19], V. Koshelev [8], O. Kruzhilko [9], T. Morozova [11], I. Ptukhina [12], A. Snirov [13], S. Shulzhenko [14], S. Hendrickson [16]. The peculiarities of public regulation of the activity of the construction industry actors and a comprehensive understanding of all the advantages and disadvantages of various methods of risk assessment in construction are still insufficiently worked out. The main task of the investor's risk analysis is to construct the correct model (presentation) of the project, which is used to make a decision to finance the construction of a particular object. The basic groups of methods for analyzing the risk of financing a project by an investor can easily be determined by the key subject of consideration - this may be either a scheme of financial flows that arise from its financing, or a project itself as a socio-economic phenomenon. The use of risk management in the management of investment and construction projects serves as a modern tool for the public regulation and risk management of construction companies.

Keywords: public regulation in the field of construction, risk management, risk assessment methods, investment and construction projects.

Постановка проблеми. В умовах недосконалості механізмів державного регулювання економічних відносин у країні організації різних типів і розмірів стикаються із зовнішніми та внутрішніми чинниками та впливами, через які стає неможливо визначити, яким чином і коли вони зможуть досягти своїх цілей. Хоча існує безліч апробованих світовим досвідом кількісних, описових, імітаційних підходів до управління ризиком інвестиційного проекту в реальному секторі, однак весь спектр методів на практиці широко не за- стосовується. Найчастіше обмежуються елементарним ранжуванням ризикованості тих чи інших проектів і зведенням правил щодо віднесення проектів до тієї чи іншої категорії ризикованості.

Під час роботи з простими проектами ця методика виправдовує себе, але зі зростанням складності проектів ризик-менеджмент стає неможливим без залучення більш детальних розробок. А для цього необхідне врахування особливостей державного регулювання діяльності суб'єктів будівельної галузі та комплексне 
розуміння усіх переваг і недоліків різних методів оцінювання ризиків у будівництві. Тому на практиці усе частіше застосовується такий ефективний управлінський інструментарій як ризик-менеджмент.

Аналіз останніх досліджень i публікацій. Через значну непередбачуваність капіталовкладень в українську будівельну галузь аналіз ризику займає особливо важливе місце в передінвестиційних дослідженнях фірм, що працюють на українському ринку. Методи оцінювання ризиків розглядаються у працях вітчизняних і зарубіжних вчених, зокрема таких, як С. Болотін [3], Н. Бланас, К. Сіракуліс та Х. Пандемменоу [19], В. Кошелев [8], О. Кружилко [9], Т. Морозова [11], I. Птухіна [12], А. Шниров [13], С. Шульженко [14], С. Хендріксон [16]. Проблематика державного регулювання оцінювання ризиків при будівництві та експлуатації споруд, управління ризиками та концепт ризик-менеджменту $є$ предметом досліджень I. Азарова [1], К. Басенко [2], Ф. Вінгбін [20], І. Власенко [4], О. Воскобійник [5], Н. Джил та Б. Тезер [17], А. Калашнікова [7], В. Мелко [10].

Метою статті $€$ аналіз використання ризик-менеджменту в управлінні інвестиційно-будівельними проектами як сучасного інструментарію механізму державного регулювання у сфері будівництва через з'ясування придатності для застосування при будівництві та експлуатації споруд методів оцінювання ризиків (на основі ISO 31010-2011).

Виклад основного матеріалу. Наразі в економіці України склалася ситуація, коли сама економіка - основні виробничі фонди, застарілі технології, технічні та технологічні системи об’єктів будівництва є джерелом ризиків аварій і катастроф. Об'єктивно існуюча і принципово непереборна невизначеність, що має місце при прийнятті державно-управлінських, організаційно-економічних i проектних системно-технічних рішень, призводить до того, що ризик таких рішень ніколи не буває нульовим. Ризик притаманний кожному проекту, кожному процесу і кожному рішенню на всіх стадіях життєвого циклу проекту. Тому ризик повинен бути керованим на кожній стадії, а це можливо лише за умови інтеграції ризик-менеджменту в управління інвестиційно-будівельними проектами та будівельною галуззю загалом.

Процес управління ризиком починається з його ідентифікації. Протягом усього процесу організації здійснюють комунікації і консалтинг із зацікавленими сторонами, аналізують ризик і засоби управління, які модифікують його з метою забезпечення того, що подальша обробка ризику не буде потрібною.

Державне регулювання у цій сфері має міцне міжнародне нормативне підгрунтя. Зокрема, розроблено відповідний стандарт (ISO 31010-2011), який детально описує систематичний та логічний процес управління ризиками. У той час як усі організації управляють ризиком до певної міри, цей Стандарт встановлює певні принципи, при виконанні яких управління ризиками стає більш ефективним.

Розвиненим є і механізм державного регулювання ризиків через 
страхування у будівельній сфері. Як зазначає В. Мелко, світова практика виробила два принципових підходи до державного регулювання ризиків у будівництві: континентальний (Німеччина, Франція, Італія, Іспанія, Японія) та англо-американсъкий (США, Велика Британія, Канада, Австралія). Континентальна система заснована на суворій законодавчій регламентації діяльності суб'єктів ринку, при цьому закони та кодекси детально регламентують усі сторони діяльності суб'єктів будівельної сфери i систематичний контроль за дотриманням законодавства при проведенні страхових операцій. Для континентальної моделі державного регулювання характерні такі форми, як перевірка виконання бізнес-планів, нагляд за поточними операціями, регулярні перевірки страхових компаній тощо. В англо-американській системі більшість сторін господарського життя не кодифіковано. Законодавство визначає лише найзагальніші умови, правові рамки державного регулювання економічної діяльності, без детальної регламентації. У межах цієї правової системи будується ліберальна модель державного регулювання, в якій основна увага приділяється контролю фінансового стану компаній на основі вивчення їх звітності [10, с. 47].

Стандарт ISO 31010-2011 розглядає ризик як вплив невизначеності на досягнення цілей організацією. Система державного регулювання та управління ризиками організацій будівельного комплексу, на думку К. Басенко, включає:

“1) діюче нормативне, правове, програмне, інформаційне, матері- ально-технічне, кадрове забезпечення, організаційну культуру, у рамках яких здійснюється функціонування будь-якої системи управління;

2) об’єкт управління - ризик, ризикові та економічні інвестиції, а також соціально-ризикові відносини, що виникають у процесі реалізації ризику;

3) суб'єкт управління - спеціальна група людей (структурний підрозділ: відділ, служба або менеджер по ризику, фінансовий менеджер та ін.), що здійснює цілеспрямоване функціонування об’єкта управління різними прийомами і методами управлінської діі” [2, с. 57].

Дослідниця I. Азарова (м. Одеса), відповідно до поширеного в зарубіжних країнах підходу Construction Risk Management System (CRMS), пропонує процес ідентифікації ризиків розглядати як послідовність шести етапів [1, с. 12]:

1) виявлення невизначеностей;

2) складання попереднього контрольного списку;

3) сценарії наслідків;

4) відображення ризиків;

5) систематизований перелік ризиків;

6) сумарний ризик.

Оцінювання ризику може бути виконане з різним ступенем глибини і деталізації з використанням одного або кількох методів різного рівня складності. Форма оцінки та ㄲi вихідні дані повинні бути сумісні з критеріями ризику, встановленими при визначенні сфери застосування. При виборі методу оцінювання ризику необхідно враховувати, що метод повинен [8]:

- відповідати ситуацї, що розглядається, і організації; 
- надавати результати у формі, що сприяє підвищенню обізнаності про вид ризику і способи його обробки;

- забезпечувати простежуваність, відтворюваність і верифікацію процесу і результатів.

Таким чином основним завданням аналізу ризику інвестором є побудова коректної моделі (подання) проекту, яка використовується для прийняття рішення про фінансування спорудження того чи іншого об'єкта. Базові групи методів аналізу ризику фінансування проекту інвестором легко визначити по ключовому предмету розгляду - це може бути або схема фінансових потоків, що виникають при його фінансуванні, або власне проект як соціально-економічний феномен.

Держава здійснює нагляд та регулювання будівельної діяльності в країні, державне управління в цій сфері покладено на Міністерство регіонального розвитку, будівництва та житлово-комунального господарства України, через яке Кабінет Мiністрів України спрямовує і координує діяльність інших центральних органів виконавчої влади, зокрема Державної архітектурно-будівельної інспекції України, у віданні якої і є контроль за дотриманням вимог законодавства, будівельних норм, стандартів і правил у будівництві. Мінрегіон провадить моніторинг ризиків у процесі будівництва та експлуатації споруд та висуває законодавчі й інші нормативно-правові подання щодо покращення державного регулювання у сфері будівництва.

Слід зауважити, що для процесів будівництва характерні особливості, що визначають види, ступінь впливу ризикових факторів, а також комплекс методів та інструментів діагностики. Будівельні ризики з'являються у результаті будівництва об'єктів і викликають відхилення ходу будівництва від планових завдань. Види ризиків, що зустрічаються при реалізації проекту, різноманітні. У загальному вигляді їх можна розділити на внутрішні і зовнішні. Основними зовнішніми ризиками є природні, економічні, технічні та адміністративні ризики. До них належать, 3окрема, ризики виникнення форс-мажорних обставин, зміни політичного середовища, курсу валют, інфляції, зміни відсоткової ставки.

Внутрішні ризики поділяються на ресурсні ризики, класифікуються за видами ресурсів, споживаних у процесі будівництва, втрати яких можуть виникнути на різних етапах будівництва, і партнерські ризики, що включають контрактні, об’єктні, ризики взаємодії між суб'єктами системи поставок і ризики управління потоковими процесами. Партнерські ризики включають ризики недопоставки сировини та комплектуючих, поставки неякісних матеріалів і компонентів, порушення строків поставки, недостатнього фінансування. До технологічних ризиків будівництва відносять передконструкційні (технічні характеристики, планування, будівництво, випробування та прийняття в експлуатацію) і постконструкційні (експлуатація об'єктів та підтримка їх експлуатаційної придатності).

Пильна увага органів державного регулювання будівельної діяльності приділяється до такої особливої групи внутрішніх ризиків, які характери- 
зують суспільний характер продукту будівельної діяльності, як ризик від можливої його відмови. Врахування актуальних ризиків можливої відмови (неможливості використовувати об'єкт або його складову за функціональним призначенням) є основою для диференціації ступеня і методів державного регулювання щодо об'єктів будівництва.

Оскільки зовнішні ризики не піддаються впливу, основна увага спрямована на управління внутрішніми ризиками [9].

Виходячи із сутності i завдань управління інвестиційно-будівельними проектами, для оцінювання та управління ризиком проектування i будівництва, а також фінансових відносин, що виникають у ході ресурсного забезпечення будівельних проектів, використовується система ризик-менеджменту. Виявлення особливостей застосування ризик-менеджменту в інвестиційно-будівельному проектуванні вимагає аналізу алгоритмів оцінки та управління ризиками. Слід зауважити, що розроблені до теперішнього часу загальні підходи до управління ризиками не враховують специфіки їх застосування в конкретних галузях економіки, i, зокрема, в інвестиційно-будівельній сфері. Проблема оцінювання невизначеності i ризику при управлінні інвестиційно-будівельними проектами донині не отримала належного вирішення. Багато в чому це зумовлено тим, що методи оцінювання ризиків, які використовуються при техніко-економічному обгрунтуванні об’єктів будівництва i реконструкції, далеко не повною мірою враховують специфіку буді- вельної діяльності й особливості експлуатації об'єктів будівництва. До основних недоліків методів, що визначають проблеми управління ризиками в інвестиційно-будівельній діяльності, слід віднести: відсутність, звичайно, кількісного виміру, а отже, оцінювання ступеня невизначеності $\mathrm{i}$ ризику основних умов реалізації будівельних проектів; випадковий характер визначення (без проведення відповідного якісного i кількісного аналізу) можливих змін в параметрах інвестиційних проектів при їх реалізації; відсутність будь-якого обгрунтування доцільності використання в заданих умовах того чи іншого методу оцінювання впливу факторів ризику на параметри інвестиційного проекту в будівельній діяльності; використання тільки монопараметричного підходу до оцінки ризиків, незважаючи на часто наявну на практиці взаємозумовленість основних параметрів інвестиційно-будівельних проектів; відсутність будь-яких рекомендацій з моніторингу ризиків у процесі реалізації інвестиційних будівельних проектів.

У зв’язку з цим необхідно враховувати, що весь процес управління ризиками (див. рис.) в ході реалізації інвестиційно-будівельного проекту слід визначати як послідовність організаційно-техніко-економічних рішень і дій, спрямованих на регулювання ймовірності успішної реалізації проекту. При цьому потрібно, щоб успішна реалізація проекту була здійснена в межах запланованого терміну і певного бюджету з належною якістю, що забезпечує необхідний рівень безпеки будівельного проекту на стадії його будівництва 


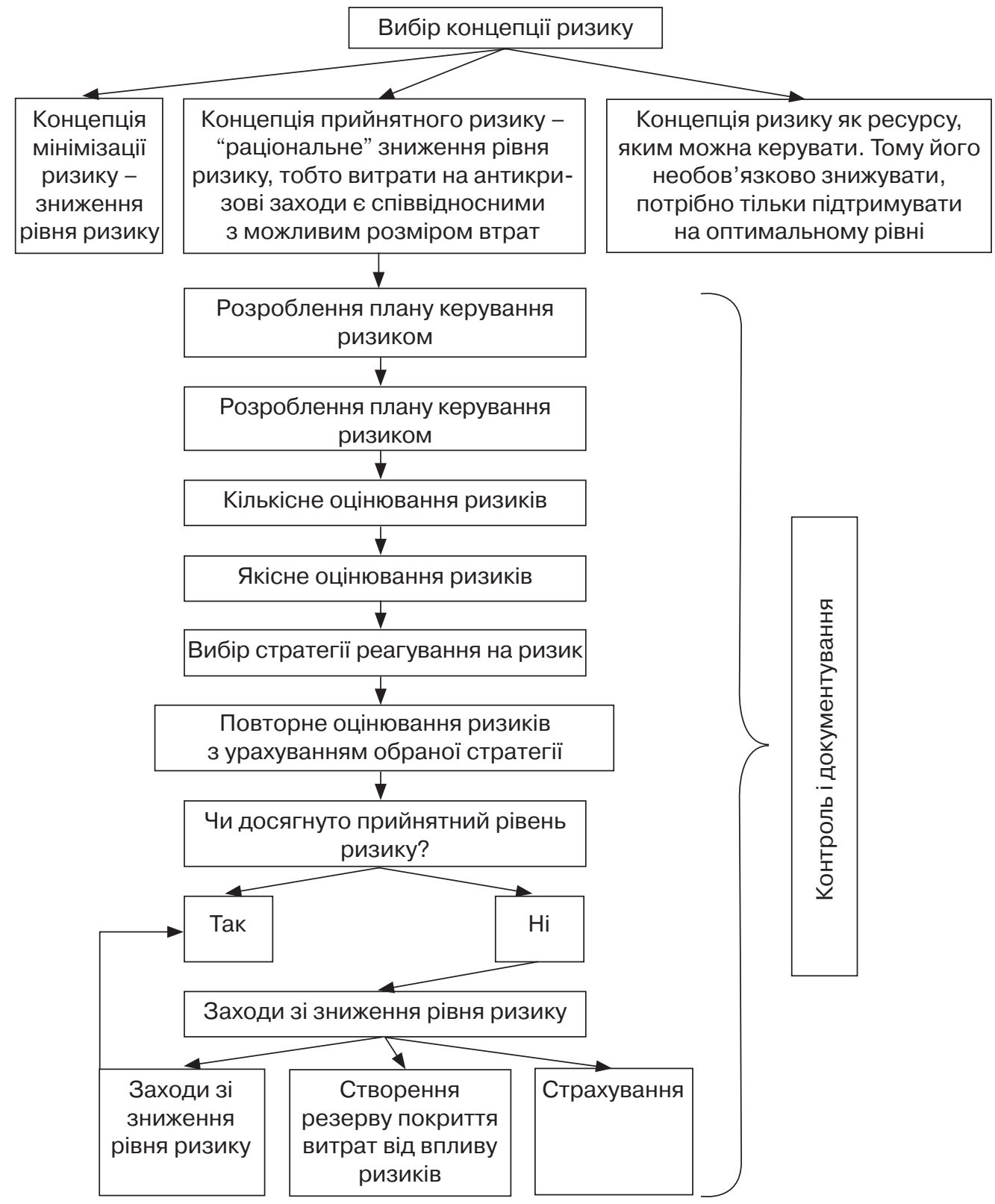

Загальний алгоритм управління ризиками інвестиційно-будівельного проекту* ${ }^{*}$ Складено авторами

і подальшої безпечної експлуатації споруд.

Аналіз ризику дає можливість при прийнятті рішень у ризикових ситуаціях визначити тенденції зміни майбутньої невизначеності [2]. Існують різні методики оцінювання ризиків, кожна з яких має як позитивні, так i негативні сторони (див. табл.).

Виокремлюють чотири великі групи методів оцінювання ризиків, а came: 
Переваги та недоліки основних груп методів аналізу ризику

\begin{tabular}{|c|c|c|c|}
\hline $\begin{array}{l}\text { Група } \\
\text { методів }\end{array}$ & $\begin{array}{c}\text { Базовий принцип } \\
\text { розроблення }\end{array}$ & Переваги & Недоліки \\
\hline $\begin{array}{l}\text { Абстрактні } \\
\text { фінансові } \\
\text { методи }\end{array}$ & $\begin{array}{l}\text { Оцінювання достат- } \\
\text { ньої суми додатково- } \\
\text { го забезпечення, яке } \\
\text { повинен мати потен- } \\
\text { ційний інвестор }\end{array}$ & $\begin{array}{l}\text { За наявності достат- } \\
\text { нього забезпечення } \\
\text { мінімізується ризик } \\
\text { участі в проекті }\end{array}$ & $\begin{array}{l}\text { Спектр доступних видів } \\
\text { забезпечення в Украї- } \\
\text { ні є дуже обмеженим, } \\
\text { оцінка якості забезпе- } \\
\text { чення також складне } \\
\text { завдання }\end{array}$ \\
\hline $\begin{array}{l}\text { Модифікації } \\
\text { фінансових } \\
\text { методів }\end{array}$ & $\begin{array}{l}\text { Оцінка цінності ре- } \\
\text { альних грошових по- } \\
\text { токів проектів для по- } \\
\text { тенційного інвестора }\end{array}$ & $\begin{array}{l}\text { Вигоди та ризики } \\
\text { участі в різних про- } \\
\text { ектах можна легко } \\
\text { порівняти }\end{array}$ & $\begin{array}{l}\text { Врахування усіх аспек- } \\
\text { тів ризику апріорі не є } \\
\text { можливим }\end{array}$ \\
\hline $\begin{array}{l}\text { Експертні } \\
\text { методи }\end{array}$ & $\begin{array}{l}\text { Систематизація уяв- } \\
\text { лень спеціалістів про } \\
\text { реалізацію аналогіч- } \\
\text { них проектів }\end{array}$ & $\begin{array}{l}\text { За допомогою цих } \\
\text { методів можна най- } \\
\text { повніше висвітлити } \\
\text { усі ризики проектів }\end{array}$ & $\begin{array}{l}\text { Експерті уявлення різ- } \\
\text { них спеціалістів важко } \\
\text { співвіднести з існуючою } \\
\text { фінансовою терміноло- } \\
\text { гією }\end{array}$ \\
\hline $\begin{array}{l}\text { Модифікації } \\
\text { експертних } \\
\text { методів }\end{array}$ & $\begin{array}{l}\text { Заміна експертних } \\
\text { оцінок певними зна- } \\
\text { ченнями фінансових } \\
\text { змінних на основі іс- } \\
\text { нуючої практики }\end{array}$ & $\begin{array}{l}\text { В ідеалі таким чином } \\
\text { можна отримати фі- } \\
\text { нансову оцінку ри- } \\
\text { зику, яка основана } \\
\text { на уявленні широко- } \\
\text { го кола спеціалістів }\end{array}$ & $\begin{array}{l}\text { Вплив аспектів ризику } \\
\text { на доходи конкретного } \\
\text { інвестора зазвичай не } \\
\text { може бути стандарти- } \\
\text { зовано та нормовано }\end{array}$ \\
\hline
\end{tabular}

* Складено авторами.

1. Теоретичні фінансові методи це оцінка необхідного забезпечення на випадок невдачі проекту (сума забезпечення може бути достовірно оцінена), оцінювання розміру шкоди та упущеної вигоди, які може зазнати інвестор.

2. Модифікації абстрактних методів - комп'ютерне моделювання проекту, що дає можливість вирахувати точні фінансові потоки. Однак вплив усіх, особливо специфічних, факторів не може бути врахований.

3. Експертні методи - опис ризику експертними оцінками. Вони включають загальну кількісну або рангову оцінку ризикованості будівельного проекту, а також опис та ранжування аспектів проекту, які є джерелами ризику.
4. Модифікації експертних методів - спроби привести в експертних оцінках до абстрактних фінансових показників. Може використовуватися, наприклад, кумулятивна побудова ставки, виокремлення груп найменш ризикованих проектів на основі переліку об'єктів потенційного фінансування.

Аналіз чутливості дозволяє оцінити вплив різних чинників на ключові показники реалізації проекту. Для житлового будівництва такими факторами є зміни закупівельних цін, стабільність роботи технічних засобів, безперервність забезпечення будівельних ділянок матеріалами, якість виконання зобов'язань підрядниками. У процесі аналізу оцінюються граничні значення факторів ризику. Загалом аналіз чутливості 
допомагає виявити фактори, які здійснюють максимальний вплив на результати проекту, а також вибрати найбільш стійкий до ризиків варіант реалізації проекту [13]. Однак у даній методиці не піддається аналізу кореляційний взаємозв'язок та взаємозалежність між показниками, не досліджується можливість прийняття альтернативних рішень.

За допомогою аналізу ймовірного розподілу дохідності можна розглядати ризик з урахуванням часу, але є і негативний бік - суб'єктивність отриманих значень прибутковості i ймовірностей їх здійснення.

Імітаційна модель дозволяє аналізувати, піддавати оцінці варіанти прийнятого рішення, а також одночасно враховувати кілька факторів ризику. Слабкою стороною такої методики є те, що в ризиковій ситуації складно знайти альтернативні шляхи вирішення, а якщо аналізу піддається ситуація, яка не має аналогів, то застосовувати дану методику важко.

За допомогою методики оцінки ризику на основі експертного методу, а також аналізу якості кредиту можна знайти найістотніші ризики i середні ймовірності їх настання, але отримані результати будуть носити суб'єктивний характер.

Завдяки моделі, заснованої на застосуванні ланцюгів Маркова, можна визначити поведінку виробничої системи в будь-який період, віддалений від початкового. Мінусом $є$ математичні труднощі при побудові перехідної матриці при аналізі економічних об'єктів, а також складний добір вірогідних відомостей.

Методика на основі комплексного показника ризику дає можливість врахувати найважливіші чинники усіх боків виробничої діяльності підприємства, дозволяє проаналізувати вплив факторних показників на результуючий в їх взаємозалежності i визначити групи факторів, що найбільш впливають на ступінь ризику [3].

На наш погляд, для оцінювання ризиків з метою диференціації регуляторного впливу держави при спорудженні й експлуатації будівель і споруд така методика $є$ найбільш прийнятною, оскільки дозволяє комплексно оцінити ризик від можливої їх відмови, який визначається залежно від потенційної небезпеки для здоров’я і життя людей, що постійно або періодично перебувають на об'єкті чи зовні; обсягу можливого економічного збитку; можливості втрати об'єктів культурної спадщини; припинення функціонування об'єктів інженерно-транспортної інфраструктури. Певним недоліком застосування цієї методики є деяка узагальненість та усередненість підходів, яка недостатньо відображає особливості конкретних проектів та динаміку зміни ризиків протягом їх життєвого циклу.

Водночас слід відзначити, що в управлінні інвестиційно-будівельними проектами сформувалися деякі загальні підходи, які дозволяють визначити послідовність дій при дослідженні ризиків в інвестиційно-будівельній сфері:

1) виділяється ризик, що володіє найбільшою важливістю для проекту;

2) розраховується перевитрата коштів 3 урахуванням імовірності настання несприятливої екологічної 
ситуації в реалізації інвестиційно-будівельного проекту;

3) розробляється комплекс організаційно-техніко-економічних заходів, які передбачають зниження ймовірності ризикової події;

4) розраховуються додаткові витрати на реалізацію антиризикових заходів;

5) виконується порівняння необхідних витрат на реалізацію запропонованих заходів з можливою перевитратою коштів унаслідок настання ризикової ситуації;

6) приймається рішення про реалізацію або про відмову від антиризикових заходів;

7) вибирається наступний за важливістю ризик, для якого повторюється процес зіставлення ймовірності і наслідків ризикових подій з витратами на заходи щодо їх зниження [2].

Існуючі методи оцінювання ризиків при проектуванні, будівництві, реконструкції, ремонті та експлуатації будівель і споруд потребують подальшого розвитку. Особливо це стосується управління інвестиційними ризиками в будівельній діяльності. Причиною тому є мінливі ціни на будівельні матеріали і конструкціï, транспортування і експлуатацію будівельних машин, механізмів та устаткування, перевезення робітників на об'єкти будівництва, витрати на відрядження при виконанні робіт в інших регіонах і на віддалених об'єктах. З'являються нові види витрат (плата за землю, нові види податків і зборів, різні види страхування, витрати на отримання вихідних даних, технічних умов і погоджень, відсотки за кредитами та ін.). Усе це свідчить про те, що ймовірнісна при- рода будівельного виробництва вимагає розвитку теорії управління інвестиційно-будівельними проектами в умовах ризиків.

Висновки та перспективи подальших досліджень. Таким чином, використання ризик-менеджменту в управлінні інвестиційно-будівельними проектами виступає сучасним інструментарієм механізму державного регулювання та управління ризиками організацій будівельного комплексу. Відповідно до міжнародного стандарту ISO 31010-2011 оцінка ризику в ході ризик-менеджменту здійснюється з різним ступенем глибини і деталізації та з використанням одного або кількох методів різного рівня складності. Однак, застосовуючи будь-яку методику, завжди треба враховувати як іii позитивні, так i негативні сторони.

Наразі у сучасній Україні існує низка обмежень для використання традиційних методів аналізу ризику, що вимагає вдосконалення державного регулювання діяльності суб'єктів будівельної галузі загалом та управління ризиками організацій будівельного комплексу зокрема. Серед проблем, які вимагають державного урегулювання, можна назвати достатньо вузький спектр видів забезпечення, проблеми оцінювання якості забезпечення, неможливість врахування усіх існуючих аспектів ризику, співвідношення експертних уявлень та фінансової термінології, стандартизації та нормування впливу аспектів ризику на конкретного інвестора. Для нівелювання недоліків абстрактно фінансових та експертних методів оцінки ризиків при будівництві можна враховувати розши- 
рений перелік чинників ризику, які впливають на участь у проекті конкретного інвестора, більш коректне використання експертних та якісних оцінок при прийнятті управлінських, проектних, фінансових, технологічних рішень.

\section{СПИСОК ВИКОРИСТАНИХ ДЖЕРЕЛ}

1. Азарова I. Б. Управління ризиками проектів у галузі житлового будівництва / І. Б. Азарова // Управління розвитком складних систем. 2015. - Вип. 23 (1). - С. 11-20.

2. Басенко К. О. Поєднання прямого та непрямого державного впливу на зменшення інвестиційних ризиків у будівельному комплексі / К. О. Басенко // Агросвіт. - 2013. - № 12. C. $55-60$.

3. Болотин C. A. Конвергенция организационно-технологического и архитектурно-строительного проектирования ориентированного на энергоресурсосбережение при строительстве и эксплуатации зданий: монография / С. А. Болотин, А. Х. Дадар. - СПб. : СПбГАСУ, 2010. - 143 с.

4. Власенко I. M. Теоретичні засади процесів державного управління ризиками у будівництві та експлуатації споруд / I. М. Власенко // Інвестиції: практика та досвід. 2018. - № 1. - C. 122-124.

5. Воскобійник О. П. Сучасний стан проблеми керування технічними ризиками (ризик-менеджмент) у будівництві / О. П. Воскобійник, О. В. Семко // Наук. пр.: Зб. Полтав. нац. тех. ун-ту ім. Ю. Кондратюка. 2015. - Вип. 1. - С. 35-44. - Серія: Галузеве машинобудування, будівництво.

6. ИСО/МЭК 31010-2011 // Менеджмент риска. Методы оценки риска. М.: Стандартинформ, 2012. - C. 1113.
7. Калашников A. A. Организация, управление и планирование в строительстве. Базовые принципы и основы организации инвестиционно-строительных проектов / А. А. Калашников, Н. И. Ватин. - СПб.: Издво Политех. ун-та, 2011. - 189 с.

8. Кошелев В. А. Анализ рисков в жилищном строительстве: методы и инструменты / В. А. Кошелев, Л. А. Сосунова // Рос. предпринимательство. - 2014. - № 3 (249). - С. 34-41.

9. Кружилко О. Є. Застосування модифікованого матричного методу оцінювання виробничого ризику на підприємствах будівельної галузі / О. Є. Кружилко, Я. Б. Сторож, О. В. Богданова, І. З. Лютак // Вісті Донец. гірничого ін-ту. - 2017. № 1. - C. 107-112.

10. Мелко В. Л. Імплементація міжнародного досвіду державного регулювання страхування ризиків будівельної діяльності в Україні / В. Л. Мелко // Аспекти публіч. упр. - 2016. - № 37-38. - С. 40-49.

11. Морозова Т. Ф. Организация поточной застройки кварталов объектами соцкультбыта / Т. Ф. Морозова, Н. Н. Боковая, Ц. Ся // Строительство уникальных зданий и сооружений. - 2013. - № 1. - С. 36-46.

12. Птухина И. С. Развитие стоимостного инжиниринга в строительстве / И. С. Птухина, А. А. Лисков, И. А. Птухин // Строительство уникальных зданий и сооружений. 2012. - № 5. - С. 17-20.

13. Шнырова А. И. Современные методики оценки рисков в строительстве / А. И. Шнырова / Инновационная наука. - 2015. - № 12-2.

14. Шульженко C. H. Формирование комплексных строительных программ в вероятностных условиях градостроительства / С. Н. Шульженко. - М. : Тульский полиграфист, 2009. - 139 с. 
15. A Guide to the Project Management Body of Knowledge Philadelphia (USA): Project Management Institute. - URL: http://www.sovnet.ru/ pages/public/pm_risk.htm

16. Hendrickson $C$. Project Management for Construction Fundamental Concepts for Owners, Engineers, Architects and Builders. Carnegie Mellon University, Pittsburgh. - URL: http:// pmbook.ce.cmu.edu/index.html

17. Gil N., Tether B. S. Project risk management and design flexibility: Analysing a case and conditions of complementarity // Research Policy. - 2011. - Vol. 40. - P. 415-428.

18. Industry Models of Risk Management and their Future. - URL: http:// www.risksig.com/articles/index.html

19. Pandremmenou H., Sirakoulis K., Blanas $N$. Success factors in the management of investment projects: a case study in the region of thessaly // Procedia - Social and Behavioral Sciences. - 2013. - Vol. 74. - P. 438-447.

20. Yingbin Feng. Effect of safety investments on safety performance of building projects // Safety Science. 2013. - Vol. 59. - P. 28-45.

\section{REFERENCES}

1. Azarova I. B. (2015). Upravlinnia ryzykamy proektiv u haluzi zhytlovoho budivnytstva [Risk Management of Housing Projects]. Upravlinnia rozvytkom skladnykh system - Management of complex systems development, 23(1), 11-20 [in Ukrainian].

2. Basenko K. O. (2013). Poiednannia priamoho ta nepriamoho derzhavnoho vplyvu na zmenshennia investytsiinykh ryzykiv $\mathrm{u}$ budivelnomu kompleksi [A combination of direct and indirect state influence on the reduction of investment risks in the construction complex]. Ahrosvit - Agrosvit, 12, 55-60 [in Ukrainian].
3. Bolotin S. A., Dadar A. Kh. (2010). Konvergentsiya organizatsionnotekhnologicheskogo i arkhitekturnostroitel'nogo proektirovaniya orientirovannogo na energoresursosberezhenie pri stroitel'stve i ekspluatatsii zdaniy [Convergence of organizational and technological and architectural and construction design focused on energy and resource conservation in the construction and operation of buildings]. Saint Petersburg: SPbGASU [in Russian].

4. Vlasenko I. M. (2018). Teoretychni zasady protsesiv derzhavnoho upravlinnia ryzykamy u budivnytstvi ta ekspluatatsii sporud [Theoretical principles of the processes of public risk management in the construction and operation of buildings]. Investytsii: praktyka ta dosvid - Investments: practice and experience, 1, 122-124 [in Ukrainian].

5. Voskobiinyk O. P., Semko O. V. (2015). Suchasnyi stan problemy keruvannia tekhnichnymy ryzykamy (ryzyk-menedzhment) u budivnytstvi [Modern state of the problem of technical risk management (risk management) in construction]. Zbirnyk naukovykh prats [Poltavskoho natsionalnoho tekhnichnoho universytetu im. Yu. Kondratiuka]. Ser.: Haluzeve mashynobuduvannia, budivnytstvo - Collection of scientific works [Poltava National Technical University named after Yu. Kondratyuk]. Series: Sectoral engineering, construction, 1, 35-44 [in Ukrainian].

6. Menedzhment riska. Metody otsenki riska [Risk management. Risk assessment techniques]. (2012). ISO/IEC 31010:2009 from December 1, 2011. № 680-ст. Moscow: Standartinform [in Russian].

7. Kalashnikov A. A., Vatin N. I. (2011). Organizatsiya, upravlenie i planirovanie v stroitelstve. Bazovye printsipy i osnovy organizatsii investitsionnostroitelnykh proektov [Organization, 
management and planning in construction. Basic principles and principles of organization of investment and construction projects]. Saint Petersburg: Izd-vo Politekhn. un-ta [in Russian].

8. Koshelev V. A., Sosunova L. A. (2014). Analiz riskov v zhilishchnom stroitelstve: metody i instrumenty [Analysis of risks in housing construction: methods and tools]. Rossiyskoe predprinimatelstvo - Russian Entrepreneurship, 3 (249), 34-41 [in Russian].

9. Kruzhylko O. Ye., Storozh Ya. B., Bohdanova O. V., Liutak I. Z. (2017). Zastosuvannia modyfikovanoho matrychnoho metodu otsiniuvannia vyrobnychoho ryzyku na pidpryiemstvakh budivelnoi haluzi [Application of the modified matrix method for estimating production risk at the enterprises of the building industry]. Visti Donetskoho hirnychoho instytutu - Bulletin of Donetsk Mining Institute, 1, 107-112 [in Ukrainian].

10. Melko V. L. (2016). Implementatsiia mizhnarodnoho dosvidu derzhavnoho rehuliuvannia strakhuvannia ryzykiv budivelnoi diialnosti v Ukraini [Implementation of international experience in state regulation of insurance of construction activity risks in Ukraine]. Aspekty publichnoho upravlinnia - Aspects of public administration, 37-38, 40-49 [in Ukrainian].

11. Morozova T. F., Bokovaya N. N., Sya Ts. (2013). Organizatsiya potochnoy zastroyki kvartalov obektami sotskultbyta [Organization of flow building of neighborhoods by social and cultural objects]. Stroitelstvo unikalnykh zdaniy i sooruzheniy - Construction of unique buildings and structures, 1 , 36-46 [in Russian].

12. Ptukhina I. S., Liskov A. A., Ptukhin I. A. (2012). Razvitie stoimostnogo inzhiniringa $v$ stroitelstve [The development of cost engineering in construction]. Stroitelstvo unikalnykh zdaniy i sooruzheniy - Construction of unique buildings and structures, 5, 17-20 [in Russian].

13. Shnyrova A. I. (2015). Sovremennye metodiki otsenki riskov $\mathrm{v}$ stroitelstve [Modern methods of risk assessment in construction]. Innovatsionnaya nauka. - Innovative science, 12, 152-153 [in Russian].

14. Shulzhenko S. N. (2009). Formirovanie kompleksnykh stroitelnykh programm v veroyatnostnykh usloviyakh gradostroitelstva [Formation of complex construction programs in the probabilistic conditions of urban development]. Moscow: Tulskiy poligrafist [in Russian].

15. A Guide to the Project Management. Body of Knowledge. (2000). Philadelphia: Project Management Institute. Retrieved from http://www.sovnet.ru/ pages/public/pm_risk.htm [in English].

16. Hendrickson C. (1998). Project Management for Construction Fundamental Concepts for Owners, Engineers, Architects and Builders. Pittsburgh: Carnegie Mellon University. Retrieved from http://pmbook.ce.cmu.edu/index.html [in English].

17. Gil N., Tether B. S. (2011). Project risk management and design flexibility: Analysing a case and conditions of complementarity. Research Policy, 40, 415-428 [in English].

18. Industry Models of Risk Management and their Future (n.d.). www.risksig. com. Retrieved from http://www.risksig.com/articles/index.html [in English].

19. Pandremmenou H., Sirakoulis K., Blanas $N$. (2013). Success factors in the management of investment projects: a case study in the region of Thessaly. Procedia - Social and Behavioral Sciences, 74, 438-447 [in English].

20. Feng $Y$. (2013). Effect of safety investments on safety performance of building projects. Safety Science, 59, 2845 [in English]. 